\title{
Quantitative Analysis of the Relationship between Ruminal Redox Potential and pH in Dairy Cattle: Influence of Dietary Characteristics
}

\section{Yayu Huang1,2, Jean Philippe Marden³, Chaouki Benchaar4, Christine Julien³, Eric Auclair ${ }^{3}$, Corine Bayourthe ${ }^{1,2^{*}}$}

\author{
'Physiologie et Systèmes d’ Elevage, UMR1388 Génétique, Université de Toulouse INPT ENSAT, Castanet-Tolosan, \\ France \\ ${ }^{2}$ Physiologie et Systèmes d' Elevage, UMR1388 Génétique, INRA, Castanet-Tolosan, France \\ ${ }^{3}$ Phileo Lesaffre Animal Care, Marcq-en-Baroeul, France \\ ${ }^{4}$ Agriculture and Agri-Food Canada, Sherbrooke Research and Development Centre, Sherbrooke, Canada \\ Email: *ba yourthe@ensat.fr
}

How to cite this paper: Huang, Y.Y., Marden, J.P., Benchaar, C., Julien, C., Auclair, E. and Bayourthe, C. (2017) Quantitative Analysis of the Relationship between Ruminal Redox Potential and $\mathrm{pH}$ in Dairy Cattle: Influence of Dietary Characteristics. Agricultural Sciences, 8, 616-630.

https://doi.org/10.4236/as.2017.87047

Received: June 8, 2017

Accepted: July 22, 2017

Published: July 25, 2017

Copyright $(0) 2017$ by authors and Scientific Research Publishing Inc. This work is licensed under the Creative Commons Attribution International License (CC BY 4.0).

http://creativecommons.org/licenses/by/4.0/

\begin{abstract}
The ruminal redox potential $\left(E_{h}\right)$ can reflect the microbiological activity and dynamics of fermentation in the rumen. It might be an important indicator of rumen fermentation in combination with $p H$. However, the ruminal $E_{h}$ has been rarely studied in dairy cows due to the difficulty of its measurement, and the relationship between ruminal $E_{h}$ and $p H$ is not clear. The objective of this study was to investigate the relationship between ruminal $E_{h}$ and $p H$ of dairy cows by meta-analysis of systematic measurements from different experiments. A database was constructed from 22 experiments on cannulated dairy cattle including 57 dietary treatments. The ruminal $p H$ and $E_{h}$ were measured without air contact between 0 and $8 \mathrm{~h}$ post-feeding. The results demonstrated a quadratic correlation between ruminal $E_{h}$ and $p H$ with a reliable withinanimal variation $\left(E_{h}=-1697+540.7 p H-47.7 p H^{2}, n_{\text {observation }}=70, n_{\text {animal }}=26\right.$, $P<0.001, R M S E=56, A I C=597)$. The dietary characteristics $(N D F, N D F f$, $O M$, starch, degradable starch, soluble sugars contents, and the dietary ionic balance) influencing the ruminal $p H$ also affected the ruminal $E_{h}$, but not always to the same extent. Some of them still influenced the relationship between ruminal $E_{h}$ and $p H$. While the mechanism of the interaction between ruminal $E_{h}$ and $p H$ remains to be elucidated, it would be interesting to associate $E_{h}$ to microbial profile, ruminal VFA concentration and milk production performance in future studies.
\end{abstract}


Keywords

Redox Potential, $p H$, Rumen, Diet, Dairy Cow

\section{Introduction}

Oxidation-reduction conditions are classically assessed by measuring the redox potential $\left(E_{h}\right)$, also called oxidation-reduction potential (usually named ORP) expressed in millivolts $(\mathrm{mV})$. It measures the ability of a solution to accept or donate electrons and corresponds to the potential difference between a platinum electrode and a standard hydrogen electrode [1]. Oxidation-reduction and acidbase reactions are essential for the maintenance of all living organisms. The chemistry of living organisms relies even more on oxidation-reduction reactions than it does on acid-base reactions, which are more focused on proton transfers [1] [2].

The role of $E_{h}$ has been reported in many biological media such as dairy products [3], wine [4] and rumen fluid [5] [6] [7]. The ruminal $E_{h}$ can reflect the microbiological activity and dynamics of fermentation in the rumen [8]. As a matter of fact, ruminal $E_{h}$ is a mixed potential because of the strong fermentative activity involving numerous oxido-reduction couples. It reflects a weighted average of the potentials contributed by each of the redox couples as mentioned by De Laune and Reddy [9] for soil. The ruminal milieu is anaerobic with an $E_{h}$ markedly negative, reflecting a strong reducing power in absence of oxygen [6]. It has been reported that dry matter intake can cause an increase of $E_{h}$, and the higher $E_{h}$ also seems to be associated with higher concentrate proportions in the diet and lower ruminal $p H$ [7], which may indicate digestive disorder. Indeed, a low $E_{h}$ seems to be more favorable to the strict anaerobic bacteria such as fibrolytic and lactate utilizing bacteria [10]. Therefore, the ruminal $E_{h}$ might be an important indicator of rumen function along with other ruminal variables. Until now, no threshold of ruminal $E_{h}$ value has been proposed to evaluate rumen function. Since the ruminal $\mathrm{pH}$ is considered as the most direct indicator of the rumen digestive disorder and has been extensively studied [11] [12], comparing with ruminal $\mathrm{pH}$ could be helpful to interpret ruminal $E_{h}$ value.

However, compared to other ruminal parameters, the $E_{h}$ is rarely discussed in dairy cows, and the relationship between ruminal $E_{h}$ and $p H$ is not clear. Indeed, the ruminal $E_{h}$ measurement method is not standardized. Three methods of $E_{h}$ potentiometric measurements have been reported in the literature. The first one consisted of a manual suction-strainer device that pumped out ruminal fluid from a cannulated animal to measure $E_{h}$ on collected hand-samples in contact with atmospheric air, after a stabilization period of 25 to $30 \mathrm{~min}$ as recommended by Andrade et al. [13] and adapted by Giger-Reverdin et al. [14]. The two others are ex vivo measurements performed on continuously pumped rumen fluid without air contact [6] and in vivo measurements performed conti- 
nuously by wireless probes inside the rumen as described by Penner et al. [15] and adapted by Qin et al. [16]. Considerable difference in ruminal $E_{h}$ values has been reported. The major difference is due to the different reference electrodes used. By definition, $E_{h}$ is the potential difference between a platinum electrode and a standard hydrogen electrode. Some authors [13] [17] who used a reference electrode of calomel or silver chloride did not correct the raw $E_{h}$ data $(+199 \mathrm{mV}$ at $39^{\circ} \mathrm{C}$ ). Also, the accurate ruminal $E_{h}$ measurement requires strict anaerobic conditions which are not always satisfied [6].

For several years, our research team has conducted numerous experiments with simultaneous measurements of ruminal $E_{h}$ and $p H$ of dairy cows fed various diets under anaerobic conditions by ex vivo and in vivo methods. Analysis of these aggregated measurements could provide a better understanding of factors controlling ruminal $E_{h}$ and $\mathrm{pH}$, and might demonstrate a quantifiable relationship between ruminal $E_{h}$ and $p H$. The objective of this study was to investigate the relationship between ruminal $E_{h}$ and $p H$ of dairy cows by meta-analysis of systematic measurements from different experiments.

\section{Materials and Methods}

\subsection{Selection of Studies}

A database was constructed from 22 experiments with cannulated dairy cattle including 57 dietary treatments (Table 1). As explained above, due to the heterogeneity of the ruminal $E_{h}$ values reported in the literature, associated with time of measurement, anaerobic conditions and electrode used [5] [7] [8] [13] [14] [18] [19], we included in the database only experiments conducted by our research group and two others conducted in Agriculture and Agri-Food Canada (Research and Development Centre, Sherbrook, QC) to ensure a consistency of measurement methods among studies. It includes either published [7] [18] [20] [21] [22] and unpublished studies [23] [24]. Both lactating (12 experiments) and non-lactating cows (10 experiments) were used. Qualitative factors such as physiological status of animals (lactating vs. non-lactating) and site of the experiment (France vs. Canada) were collected.

All animal housing and handling procedures were in accordance with the guidelines for animal research of the French Ministry of Agriculture [25]. Cannulation techniques provided for humane treatment of cows, adhering to locally approved procedures, and were similar to those described by Streeter et al. [26]. All animals were housed in individual tie stalls throughout the experiment with free access to water. Each experimental period covered an adaptation period ( 2 to 3 weeks) to the different dietary treatment and a measurement period ( 3 days).

The diets were formulated to meet energy and protein requirements, with two equal distributions at 0900 and $1700 \mathrm{~h}$. The composition of the diets (Table 2) varied widely (e.g. the proportion of concentrate ranged from 0 to $63 \%$ ). Some of the dietary characteristics such as neutral detergent fiber from forages (NDFf $)$, ruminally degradable starch, rumen protein balance $(R P B)$ were estimated by the 
Table 1. Summarize of 22 experiments in the database.

\begin{tabular}{|c|c|c|c|c|c|}
\hline$N_{\text {exp }}^{1}$ & $\begin{array}{l}\text { Physiological } \\
\text { status }\end{array}$ & $\begin{array}{l}\text { Experimental } \\
\text { design }\end{array}$ & $\begin{array}{l}\text { Method }{ }^{2} \text { for } \\
\text { measuring } E_{h}\end{array}$ & Main ingredients of diets & Reference \\
\hline 1 & Non-lactating & Latin square & 1 & Corn silage/wheat/corn/soybean meal & Unpublished \\
\hline 2 & Lactating & Latin square & 1 & Corn silage/alfalfa hay/composed concentrate & [23] \\
\hline 3 & Lactating & Randomized block & 1 & Corn silage/wheat/composed concentrate & Unpublished \\
\hline 4 & Non-lactating & Latin square & 1 & Corn silage/wheat grain/corn/soybean meal & Unpublished \\
\hline 5 & Non-lactating & Randomized block & 1 & Corn silage/alfalfa hay/corn/soybean meal & [21] \\
\hline 6 & Non-lactating & Latin square & 1 & Grass hay/barley/wheat/soybean meal & [7] \\
\hline 7 & Non-lactating & Randomized block & 1 & $\begin{array}{l}\text { Alfalfa hay/corn silage/wheat straw/corn/soybean } \\
\text { meal }\end{array}$ & [20] \\
\hline 8 & Lactating & Latin square & 1 & $\begin{array}{l}\text { Corn silage/wheat/soybean/meal/tanned soybean } \\
\text { meal }\end{array}$ & [22] \\
\hline 9 & Lactating & Latin square & 1 & Corn silage/wheat/corn/soybean meal & [24] \\
\hline 10 & Lactating & Latin square & 1 & Corn silage/wheat/corn/soybean meal & [24] \\
\hline 11 & Lactating & Latin square & 2 & $\begin{array}{l}\text { Alfalfa silage/corn silage/grass hay/corn/soybean } \\
\text { meal }\end{array}$ & Benchaar et al., unpublished \\
\hline 12 & Non-lactating & Randomized block & 1 & Corn silage/wheat/corn/soybean meal & Unpublished \\
\hline 13 & Lactating & Latin square & 2 & $\begin{array}{l}\text { Corn silage/alfalfa hay/soybean meal/composed } \\
\text { concentrate }\end{array}$ & Unpublished \\
\hline 14 & Non-lactating & Latin square & 2 & Grass hay/soybean meal & Unpublished \\
\hline 15 & Lactating & Latin square & 1 & $\begin{array}{l}\text { Grass hay/wheat/corn/soybean meal/composed } \\
\text { concentrate }\end{array}$ & Unpublished \\
\hline 16 & Non-lactating & Latin square & 1 & Corn silage/wheat/corn/soybean meal & Unpublished \\
\hline 17 & Non-lactating & Latin square & 1 & Corn silage/wheat/corn/soybean meal & Unpublished \\
\hline 18 & Lactating & Latin square & 1 & Corn silage/alfalfa hay/composed concentrate & [23] \\
\hline 19 & Non-lactating & Randomized block & 1 & Corn silage/wheat/corn/soybean meal & Unpublished \\
\hline 20 & Lactating & Latin square & 2 & Barley silage/corn silage/barley/corn/soybean meal & Benchaar et al., unpublished \\
\hline 21 & Lactating & Latin square & 1 & Corn silage/alfalfa hay/composed concentrate & [18] \\
\hline 22 & Lactating & Latin square & 1 & Corn silage/wheat/composed concentrate & Unpublished \\
\hline
\end{tabular}

${ }^{1} N_{\text {exp }}=$ number of experiments; ${ }^{2}$ Method $1=$ measurements performed with probes on continuously pumped rumen fluid [6]; Method $2=$ measurements performed continuously with probes inside the rumen and wireless device [15].

online software "systool.fr" [27] using the equations published in Sauvant and Nozière [28]. The influence of dietary ionic balance on acid-base balance of animal has been reported [29] [30] [31], it can be expressed (in $\mathrm{mEq} / \mathrm{kg}$ of $D M$ ) as the dietary cation anion difference $(D C A D=\mathrm{Na}+\mathrm{K}-\mathrm{Cl}-\mathrm{S})$ or electrolytic balance $(\boldsymbol{E} \boldsymbol{B}=\mathrm{Na}+\mathrm{K}-\mathrm{Cl})$. We also calculated these values according to the INRA tables [32] for all the diets used in the data base.

\subsection{Measurement of Ruminal $E_{h}$ and $p H$}

A total of 775 kinetics of ruminal $E_{h}$ and $p H$ measurements were gathered together. Each kinetic includes 9 measurements of ruminal $p H$ and $E_{h}$ taken at $1 \mathrm{~h}$ 
Table 2. Descriptive variables of the diets composition $(n=57)$ for data set used in the meta-analysis.

\begin{tabular}{lcccc}
\hline \multicolumn{1}{c}{ Item } & Mean & $S D$ & Minimum & Maximum \\
\hline Intake, kg DM/cow per d & 16.6 & 7.3 & 7.7 & 27.3 \\
Proportion of concentrate, \% DM & 37.7 & 13.6 & 0.0 & 62.6 \\
$O M, \mathrm{~g} / \mathrm{kg} D M$ & 946.2 & 16.2 & 891.8 & 968.1 \\
$R P B, \mathrm{~g} / \mathrm{kg} D M$ & 4.0 & 17.8 & -27.0 & 79.4 \\
$N D F, \mathrm{~g} / \mathrm{kg} D M$ & 368.5 & 73.8 & 263.3 & 566.3 \\
$N D F f$, g/kg $D M$ & 303.0 & 92.3 & 178.5 & 566.3 \\
Starch, g/kg $D M$ & 293.6 & 126.6 & 0.0 & 503.2 \\
Degradable starch, g/kg $D M$ & 217.9 & 102.5 & 0.0 & 440.4 \\
$C P, \mathrm{~g} / \mathrm{kg} \mathrm{DM}$ & 149.0 & 23.9 & 101.1 & 222.3 \\
Soluble sugars, g/kg $D M$ & 50.6 & 28.4 & 0.0 & 105.4 \\
$D C A D, \mathrm{mEq} / \mathrm{kg} D M$ & 173.3 & 99.3 & 59.1 & 438.0 \\
$E B, \mathrm{mEq} / \mathrm{kg} D M$ & 276.9 & 119.5 & 133.8 & 638.0 \\
\hline
\end{tabular}

$D M=$ dry matter; $O M=$ organic matter; $R P B=$ rumen protein balance; $N D F=$ neutral detergent fibre; $N D F f=N D F$ from forages; $C P=$ crude protein; $D C A D=$ dietary cation anion difference $(\mathrm{Na}+\mathrm{K}-\mathrm{Cl}-\mathrm{S}$, in $\mathrm{mEq} / \mathrm{kg}$ of $\mathrm{DM}) ; E B=$ electrolytic balance $(\mathrm{Na}+\mathrm{K}-\mathrm{Cl}$, in $\mathrm{mEq} / \mathrm{kg}$ of $D M) ; S D=$ standard deviation.

intervals from the morning diet distribution to 8 hours after. The average $E_{h}$ and $p H$ of these 9 measurements have been calculated for each kinetic. The measurement of ruminal $E_{h}$ and $p H$ on each animal under each dietary treatment was repeated in three consecutive days during the measurement period.

All $E_{h}$ and $p H$ values were measured under strict anaerobic conditions, by $e x$ vivo (Method 1) [6], or in vivo method (Method 2) [15]. In Method 1, rumen fluid was pumped continuously through a rubber tube into a 50 -mL-doublewalled thermo controlled vessel outside the rumen, the $E_{h}$ and $p H$ were measured by electrodes dipped in the collected rumen fluid without air contamination. In Method 2, a wireless real-time data logger (Dascor, Escondido, CA, USA) was submersed into the ventral rumen sac via the ruminal cannula after calibration, and the $E_{h}$ and $p H$ were measured by external sensors of the data logger and stored in the memory chip. For both methods, the accuracy $E_{h}$ electrode was checked by measuring the standard solution at $220 \mathrm{mV}$ (Fishier Scientific) before and after each measurement.

Considering both methods used an $E_{h}$ platinum electrode, all records of the potential difference were corrected relative to the standard hydrogen electrode $\left(+199 \mathrm{mV}\right.$ at $\left.39^{\circ} \mathrm{C}\right)$ [33]. Moreover, as Huang et al. [34] observed an effect of the method on the $E_{h}$ value, due to the difference of sensors and location of measurements, the $E_{h}$ values measured by Method 2 were corrected $(+35.4 \mathrm{mV})$ to avoid the influence of method effect.

\subsection{Statistical Analysis}

Interpretation of the database was based on a statistical meta-analysis [35] [36]. At each step of the meta-analysis process, graphical observations were made to 
check the coherence of relationships and to identify obviously abnormal values. All analyses were performed using the statistical software R version 2.15.1 ( $R$ Development Core Team, 2012).

\subsubsection{Influence of Dietary Characteristics on $E_{h}$ and $p H$}

The average $E_{h}$ and $p H$ of each dietary treatment were calculated for this analysis. The experiment effect was considered to be random. The within-experiment correlation was calculated using a mixed model. The general form of the mixed model was:

$$
Y_{i j}=B_{0}+B_{1} X_{i j}+s_{i}+b_{i} X_{i j}+e_{i j}
$$

where $i=$ number of studies, $j=$ number of observations, $B_{0}+B_{1} X_{i j}$ is the fixed effect part of the model and $s_{i}+b_{i} X_{i j}+e_{i j}$ is the random effect part of the model. The goodness of fit of the model was evaluated using the Akaike Information Criterion (AIC) [37]. Because a reliable within-experiment response requires a minimal variation of descriptive variables, only the experiments tested a sufficient range of dietary characteristics $(O M>25 \mathrm{~g} / \mathrm{kg}$, starch $>70 \mathrm{~g} / \mathrm{kg}$, soluble sugar $>20 \mathrm{~g} / \mathrm{kg}, C P>18 \mathrm{~g} / \mathrm{kg}, N D F>80 \mathrm{~g} / \mathrm{kg}, D C A D>50 \mathrm{mEq} / \mathrm{kg}, E B>100 \mathrm{~m}$ $\mathrm{Eq} / \mathrm{kg}$ ) were selected for within-experiment analysis.

For each relationship, the number of treatments $\left(n_{\text {treat }}\right)$ and of experiments $\left(n_{\exp }\right)$ used in the analysis are reported. Treatments with high normalized residuals $(<-3$ or $>+3)$ were identified and discarded from the model as statistical outliers if they had a high leverage effect based on $H i$ calculation $(H i>3 \times \mathrm{k} / \mathrm{n}$, where $\mathrm{k}$ is number of independent variables in the model and $\mathrm{n}$ is the number of observations) and Cook distance (Cook > 1) [35]. A one-way ANOVA was used to test whether ruminal $E_{h}$ or $p H$ varied according to the qualitative factors such as physiological status and site of the experiment.

\subsubsection{Relationship between Ruminal $E_{h}$ and $p H$}

Since the individualized ruminal $E_{h}$ and $p H$ measurements are available, the average $E_{h}$ and $p H$ of each animal in each dietary treatment ( 3 repetitions) were calculated to take into account the variability within one animal under different dietary treatments. Only the animals (70 observations from 26 animals) presenting a sufficient range of ruminal $p H(\geq 0.2)$ were selected to this analysis. The within-animal correlation was calculated using a mixed model. The animal effect was considered to be random. The model was:

$$
Y_{i j}=B_{0}+B_{1} X_{i j}+s_{i}+b_{i} X_{i j}+e_{i j}
$$

where $i=$ number of animals, $j=$ number of observations, $B_{0}+B_{1} X_{i j}$ is the fixed effect part of the model and $s_{i}+b_{i} X_{i j}+e_{i j}$ is the random effect part of the model.

The influence of co-variables $(O M, N D F, N D F f$, total starch, degradable starch, $C P$, soluble sugars, $D C A D, E B$, and $R P B$ contents in diets) on the relationship between ruminal $E_{h}$ and $p H$ was tested. The first step consisted in highlighting the co-variables influencing the residuals (i.e. the difference between observed $E_{h}$ and predicted $E_{h}$ by the equation). The influence of all co-variableson residuals (observed minus predicted $E_{h}$ ) was tested using the Stepwise 
procedure. In the second step of the analysis, the significant co-variables were included in the model.

\section{Results}

A summary of $E_{h}$ and $p H$ value in the database is given in Table 3. Both $E_{h}$ (ranged from -233.4 to $-99.6 \mathrm{mV}$ ) and $p H$ (ranged from 5.48 to 6.76 ) covered a wide range.

\subsection{Influence of Dietary Characteristics on Ruminal $E_{h}$ and $p H$}

Table 4 reports the relationship between ruminal $E_{h}$ and dietary characteristics. Ruminal $E_{h}$ was positively correlated to $O M(P=0.022)$, total starch $(P=0.012)$, degradable starch $(P=0.041)$, and soluble sugars $(P<0.001)$ contents, and negatively correlated to total $\operatorname{NDF}(P=0.024), \operatorname{NDFf}(P=0.049), D C A D(P<0.001)$, and $E B(P<0.001)$. The ruminal $E_{h}$ was not related to $C P(P=0.713)$, and $R P B$ $(P=0.209)$. No experiment tested the effect of intake and only two experiments tested a sufficient range of proportion of concentrate $(\geq 30 \%)$, which did not permit the analysis of within-experiment relationship between ruminal $E_{h}$ and these two parameters.

The quadratic adjustment was significant between ruminal $E_{h}$ and $D C A D$ $\left(E_{h}=-122-0.462 D C A D+0.000596 D C A D^{2}, P=0.010, R M S E=9, A I C=187\right)$

Table 3. Summary of the redox potential and $p H$ value in the database.

\begin{tabular}{cccccc}
\hline & $n$ & Mean & $S D^{1}$ & Minimum & Maximum \\
\hline$E_{h}(\mathrm{mV})$ & 775 & -179.8 & 25.9 & -233.4 & -99.6 \\
$p H$ & 775 & 6.15 & 0.30 & 5.48 & 6.76 \\
\hline
\end{tabular}

${ }^{1} S D=$ standard deviation.

Table 4. Relationship between ruminal redox potential and dietary characteristics.

\begin{tabular}{lccccccc}
\hline \multicolumn{1}{c}{ Item } & $n_{\text {exp }}$ & $n_{\text {treat }}$ & Intercept & Slope & $P$-value & $R M S E$ & $A I C$ \\
\hline$O M, \mathrm{~g} / \mathrm{kg} D M$ & 6 & 18 & -718 & 0.559 & 0.022 & 13 & 151 \\
$R P B, \mathrm{~g} / \mathrm{kg} D M$ & 7 & 20 & $\mathrm{NS}$ & $\mathrm{NS}$ & $\mathrm{NS}$ & $\mathrm{NS}$ & $\mathrm{NS}$ \\
$N D F, \mathrm{~g} / \mathrm{kg} D M$ & 5 & 15 & -143 & -0.126 & 0.024 & 14 & 129 \\
$N D F f$, g/kg $D M$ & 5 & 15 & -165 & -0.086 & 0.049 & 15 & 131 \\
Starch, g/kg $D M$ & 6 & 18 & -215 & 0.088 & 0.012 & 13 & 153 \\
Degradable starch, g/kg $D M$ & 6 & 18 & -210 & 0.089 & 0.041 & 14 & 155 \\
$C P$, g/kg $D M$ & 6 & 18 & $\mathrm{NS}$ & $\mathrm{NS}$ & $\mathrm{NS}$ & $\mathrm{NS}$ & $\mathrm{NS}$ \\
Soluble sugars, g/kg $D M$ & 6 & 18 & -215 & 0.696 & $<0.001$ & 10 & 137 \\
$D C A D, \mathrm{mEq} / \mathrm{kg} D M$ & 8 & 22 & -154 & -0.145 & $<0.001$ & 11 & 179 \\
$E B, \mathrm{mEq} / \mathrm{kg} D M$ & 8 & 22 & -141 & -0.141 & $<0.001$ & 12 & 174 \\
\hline
\end{tabular}

$O M=$ organic matter; $D M=$ dry matter; $R P B=$ rumen protein balance; $N D F=$ neutral detergent fibre; $N D F f=N D F$ from forages; $C P=$ crude protein; $D C A D=$ dietary cation anion difference $(\mathrm{Na}+\mathrm{K}-\mathrm{Cl}-\mathrm{S}$, in $\mathrm{mEq} / \mathrm{kg}$ of $D M) ; E B=$ electrolytic balance $(\mathrm{Na}+\mathrm{K}-\mathrm{Cl}$, in $\mathrm{mEq} / \mathrm{kg}$ of $D M) ; n_{\exp }=$ number of experiments; $n_{\text {treat }}=$ number of treatments; $R M S E=$ residual mean standard error; $A I C=$ akaikeinformation criterion. 
and between ruminal $E_{h}$ and $E B\left(E_{h}=-107-0.368 E B+0.000313 E B^{2}, P=0.003\right.$, $R M S E=8, A I C=183)$. The ruminal $E_{h}$ was significantly affected by physiological status $(-188.5 \pm 24.0$ and $-169.1 \pm 20.8 \mathrm{mV}$ for non-lactating and lactating cows respectively, $P=0.002)$, but not affected by the site of experiment $(P=$ 0.353).

Table 5 reports the relationship between ruminal $p H$ and dietary characteristics. Ruminal $p H$ was positively correlated to $N D F(P=0.008), N D F f(P=0.012)$, $D C A D(P=0.004)$, and $E B(P=0.001)$, and was negatively correlated to $O M(P$ $=0.018)$, starch $(P=0.004)$, degradable starch $(P=0.018)$, and soluble sugars $(P$ $<0.001)$ contents. It was not related to $C P(P=0.195)$ and $R P B(P=0.518)$.

No quadratic adjustment was significant for relationship between ruminal $p H$ and dietary characteristics (data not shown). The ruminal $p H$ was significantly affected by physiological status $(6.32 \pm 0.25$ and $5.99 \pm 0.17$ for non-lactating and lactating cows respectively, $P<0.001$ ), but not affected by the measurement method of $E_{h}(P=0.942)$, and the site of the experiment $(P=0.950)$.

\subsection{Relationship between Ruminal $E_{h}$ and $p H$}

The relationship between ruminal $E_{h}$ and $p H$ is presented in Figure 1. The ruminal $E_{h}$ and $p H$ were negatively correlated. The linear relationship (Equation (1)) and quadratic adjustment (Equation $(2))$ were both significant $(P<0.001)$ :

$$
\begin{gathered}
E_{h}=104-46.3 p H\left(n_{\text {obs }}=70, n_{\text {anim }}=26, R M S E=17, A I C=609\right) \\
E_{h}=-1697+540.7 p H-47.7 p H^{2} \\
\left(n_{\text {obs }}=70, n_{\text {anim }}=26, R M S E=16, A I C=597\right)
\end{gathered}
$$

\subsection{Variables Influencing the Relationship between Ruminal $E_{h}$ and $p H$}

The intake $(P<0.001)$, soluble sugars contents $(P=0.008), D C A D(P=0.003)$ were selected by the Stepwise analysis and significantly influenced the residuals

Table 5. Relationship between ruminal $p H$ and dietary characteristics.

\begin{tabular}{lccccccc}
\hline \multicolumn{1}{c}{ Item } & $n_{\exp }$ & $n_{\text {treat }}$ & Intercept & Slope & $P$-value & $R M S E$ & $A I C$ \\
\hline$O M, \mathrm{~g} / \mathrm{kg} D M$ & 6 & 18 & 10.93 & -0.0049 & 0.018 & 0.11 & 2.1 \\
$R P B, \mathrm{~g} / \mathrm{kg} D M$ & 7 & 20 & $\mathrm{NS}$ & $\mathrm{NS}$ & $\mathrm{NS}$ & $\mathrm{NS}$ & $\mathrm{NS}$ \\
$N D F, \mathrm{~g} / \mathrm{kg} D M$ & 5 & 15 & 5.98 & 0.0011 & 0.008 & 0.10 & 3.5 \\
$N D F f$, g/kg $D M$ & 5 & 15 & 6.14 & 0.0008 & 0.012 & 0.10 & 4.9 \\
Starch, g/kg $D M$ & 6 & 18 & 6.57 & -0.0008 & 0.004 & 0.10 & 2.9 \\
Degradable starch, g/kg $D M$ & 6 & 18 & 6.52 & -0.0008 & 0.018 & 0.11 & 5.4 \\
$C P, \mathrm{~g} / \mathrm{kg} D M$ & 6 & 18 & $\mathrm{NS}$ & $\mathrm{NS}$ & $\mathrm{NS}$ & $\mathrm{NS}$ & $\mathrm{NS}$ \\
Soluble sugars, g/kg $D M$ & 6 & 18 & 6.54 & -0.0055 & $<0.001$ & 0.06 & -14.3 \\
$D C A D, \mathrm{mEq} / \mathrm{kg} D M$ & 8 & 22 & 6.05 & 0.0011 & 0.004 & 0.09 & 2.1 \\
$E B, \mathrm{mEq} / \mathrm{kg} D M$ & 8 & 22 & 5.97 & 0.0010 & 0.001 & 0.11 & 5.5 \\
\hline
\end{tabular}

$O M=$ organic matter; $D M=$ dry matter; $R P B=$ rumen protein balance; $N D F=$ neutral detergent fibre; $N D F f=N D F$ from forages; $C P=$ crude protein; $D C A D=$ dietary cation anion difference $(\mathrm{Na}+\mathrm{K}-\mathrm{Cl}-\mathrm{S}$, in $\mathrm{mEq} / \mathrm{kg}$ of $\mathrm{DM}) ; E B=$ electrolytic balance $(\mathrm{Na}+\mathrm{K}-\mathrm{Cl}$, in $\mathrm{mEq} / \mathrm{kg}$ of $\mathrm{DM}) ; n_{\exp }=$ number of experiments; $n_{\text {treat }}=$ number of treatments; $R M S E=$ residual mean standard error; $A I C=$ akaikeinformation criterion. 


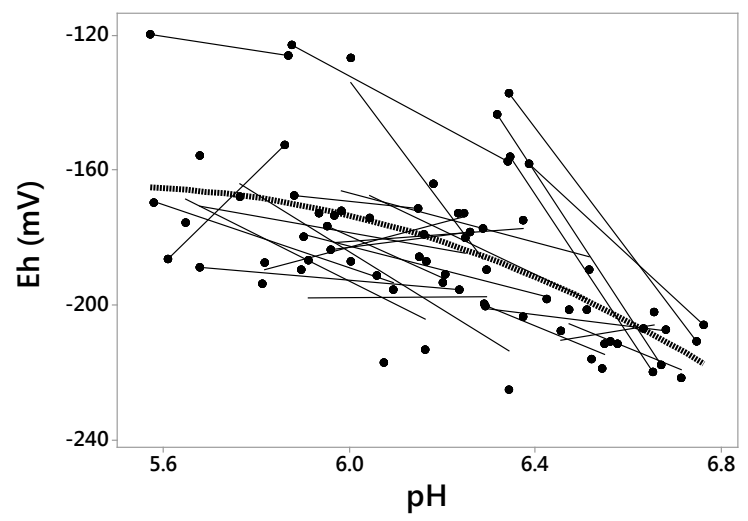

Figure 1. Relationship between ruminal redox potential $\left(E_{h}\right)$ and $p H$. Each symbol represents the data from one animal in one experiment. The solid lines represent the linear regression of the data from each animal. The dotted line represents the average within-animal quadratic adjustment of all observations $\left(E_{h}=-1697+540.7 \mathrm{pH}-47.7 \mathrm{pH}^{2}, n_{\text {observations }}=70, n_{\text {animals }}\right.$ = 26, $\left.P<0.001, R M S E=16, A I C=597, R^{2}=0.77\right)$.

of Equation (2). Once included in Equation (2), only the $D M I$ was significant ( $P$ $=0.03)$ and slightly improved the equation:

$$
\begin{aligned}
& E_{h}=-2097+690.2 p H-60.7 p H^{2}-1.27 D M I \\
& \left(n_{\text {obs }}=70, n_{\text {anim }}=26, R M S E=16, \text { AIC }=591\right)
\end{aligned}
$$

\section{Discussion}

Meta-analyses use scientific methods based on statistics to summarize and quantify knowledge acquired through previously conducted studies [35]. Until now, there is alimited number of studies reporting ruminal $E_{h}$ measurements. Unlike a classical empirical modeling of biological responses based on exhaustive data collection from published experimental results, our study used the aggregation of measurements from our experiments in order to ensure the homogeneity of $E_{h}$ values and avoided the considerable influence of measurement method explained previously. Use of such analysis leads to a better understanding of factors that controlling the variables.

The database of present study covered a wide range of ruminal $E_{h}$ and $p H$ values. The range of ruminal $E_{h}$ value in dairy cattle in our database $(-233.4$ to $-99.6 \mathrm{mV})$ is comparable with that in sheep $(-260$ to $-150 \mathrm{mV})$ [8] [19], in goat $(-190$ to $-145 \mathrm{mV})$ [5] and in dairy cow $(-241$ to $-185 \mathrm{mV})$ [38]. Some authors reported much lower ruminal $E_{h}$ values: from -340 to $-302 \mathrm{mV}$ in sheep [17] and from -352 to $-327 \mathrm{mV}$ in goat [13]. It is due to the different reference electrodes used as explained above. The significant effect of physiological status on ruminal $E_{h}$ and $p H$ was expected and could be explained by dietary difference between lactating and non-lactating cows.

\subsection{Dietary Characteristics Influencing Ruminal $E_{h}$}

The influence of dietary concentrate proportion on ruminal $E_{h}$ observed in previous studies [5] [8] [14] was not confirmed by our analysis due to the limited 
number of experiments $(n=2)$ presenting a sufficient range of dietary concentrate proportion. However, the variables associated with slowly or rapidly degradable materials contents ( $N D F, N D F f, O M$, starch, degradable starch and especially soluble sugars, which resulted low RMSE and $A I C$ ) showed consistent correlation with ruminal $E_{h}$.

Few studies investigated the influence of these dietary characteristics on ruminal $E_{h}$. However, the effect of slowly or rapidly degradable diet on ruminal $E_{h}$ has been reported. Andrade et al. [13] observed a higher ruminal $E_{h}$ for the goats fed rapidly degradable diet $(-327 \mathrm{mV})$ compared to that of goats fed slowly degradable diet $(-352 \mathrm{mV})$. These $E_{h}$ values were lower than ours due to the different reference electrodes used, but the difference of ruminal $E_{h}$ caused by two type of diet was significant $(P<0.001)$. Our results are in agreement with these observations.

To our knowledge, the effect of dietary ionic balance ( $D C A D$ and $E B)$ on ruminal $E_{h}$ has never been reported. According to our results, the $D C A D$ and $E B$ showed consistent correlation with ruminal $E_{h}$. The quadratic adjustment of the within-experiment relationship resulted slightly higher $A I C$ (187 and 183 for $D C A D$ and $E B$ respectively) but lower $R S M E$ (9 and 8 for $D C A D$ and $E B$ respectively). The mechanism of this effect remains unclear. But it is known that $E_{h}$ can affect mineral availability. As demonstrated in soil, $E_{h}$ is a factor that strongly influences the mobility of many elements such as N, P, S, K and Na. Conversely, $\mathrm{E}_{h}$ is influenced by the various elements [1]. Considering that the effect of dietary ionic balance was not investigated as a determining factor by the experiments in the database, it deserves to be confirmed by a classic experiment with in vivo measurements.

\subsection{Dietary Characteristics Influencing Ruminal $\mathbf{p H}$}

The influence of $O M, N D F, N D F f$, starch, degradable starch and soluble sugars contents on ruminal $p H$ is well documented. Among these variables, the relationship between $N D F$ and starch content and ruminal $p H$ are frequently studied. The relationship $(y=5.53+0.022 x)$ between $p H$ and diet $N D F$ content $(\%$ $D M$ ) reported by Pitt et al. [39] is close to the relationship obtained in our study. By analyzing results from 23 studies of lactating dairy cows fed pasture, Kolver and de Veth [40] reported a within study equation between ruminal $p H$ and $N D F$ content $(\% D M)$ with a numerically lower slope than ours $(y=5.84+$ $0.0075 x, P=0.014, n=100)$, when taking into account the difference of unit of $N D F$ (g/kg $D M$ in our analysis). Regarding the influence of degradable starch in the rumen (\% of intake dry matter) on ruminal $p H$ (dairy and beef cattle), Sauvant and Peyraud [11] reported a similar relationship $(y=6.4-0.01 x)$ compared to ours.

The $D C A D$ and $E B$ are close (the only difference is that the $E B$ does not consider sulfur ions) and highly correlated [41]. Both influence ruminal $p H$. Their influence on acid-base balance of animal has been described [42]. Indeed, $\mathrm{Na}$ and $\mathrm{K}$ are absorbed from the gastrointestinal tract in exchange for the secretion 
of a proton, whereas $\mathrm{Cl}$ and $\mathrm{S}$ are often absorbed in exchange for the secretion of a bicarbonate ion [31] [43]. Increasing $D C A D$ in the diet allows the cows to overcome the saturation of the renal mechanisms for saving $\mathrm{HCO}_{3}$ and contributes to increase blood bicarbonate concentration which could be recycled into the rumen to limit the decrease of ruminal $p H$. Several studies reported that a shift from negative or null $D C A D$ to highly positive values increases $D M I$ and milk yield [42] [44]. A meta-analysis [30] grouping 27 experiments reported positive relationship between $E B$ and blood $p H, E B$ and bicarbonate content in blood, $E B$ and $p H$ of urine. Our results showed clear positive relationship between $D C A D$ or $E B$ and ruminal $p H$, which is in agreement with the hypothesis of the acid-base balance mechanism in ruminant. The equation between ruminal $p H$ and $D C A D$ obtained by our analysis is consistent with that of Iwaniuk and Erdman [45], obtained by a meta-analysis of 63 published journal articles $(y=$ $\left.6.31+0.0003 x, P=0.034, r^{2}=0.19, n=83\right)$. Considering these results, $D C A D$ and $E B$ deserve to be more often measured and taken into account in future studies.

\subsection{Relationship between Ruminal $E_{h}$ and $p H$}

The results of present study confirmed the negative relationship between ruminal $E_{h}$ and $p H$ reported by previous studies in goats [5] [13] [46]. The slope of the linear relationship in our study is similar to that of Giger-Reverdin et al. [46]. The lower average ruminal $\mathrm{E}_{h}$ value $(-354 \pm 22 \mathrm{mV})$ reported by these authors could be explained by the different measurement methods used as explained previously. By gathering together a large data base of wide range ruminal $E_{h}$ and $p H$ values, we further demonstrated a quadratic correlation Equation (2) between ruminal $E_{h}$ and $p H$ with a reliable within-animal variation of the variable. Considering that in biological media, such as rumen, many oxidation-reduction reactions involve protons, it is not surprising that ruminal $E_{h}$ and $p H$ are related [1] [13] as is shown by the Nernst's equation [47].

It is noteworthy that the diet characteristics (NDF, NDFf, OM, starch, degradable starch, soluble sugars contents, and the dietary ionic balance) influencing the ruminal $p H$ also affected ruminal $E_{h}$, but not always in same extent. Indeed, the complex reactions which determine $E_{h}$ are not necessarily the same reactions which determine $p H$ : for example, when rapidly-oxidizable organic matter is added, the $E_{h}$ could be changed without changing $p H$ [48]. Also, Friedman et al. [49] highlighted the $E_{h}$ as a key factor in the structuring of anaerobic microbial communities through their experimental system separating $E_{h}$ from $p H$ effect.

In our database, we can observe some high $p H$ values (e.g. $p H>6$, without SARA according to the ruminal $p H$ thresholds proposed in the literature) associated with high $E_{h}$ which is unfavorable to activities of fibrolytic and lactate utilizing bacteria, and also some low $E_{h}$ values associated with low $p H$ (Figure 1). Therefore, in some circumstances, the $E_{h}$ could better reflect the fermentation dynamics than $\mathrm{pH}$ and vice versa. 
The measurement of ruminal $p H$ alone might not be sufficient for diagnosing digestive disorder in some cases. The simultaneous measurement of ruminal $E_{h}$ and $p H$ could be useful to provide complementary information about the rumen fermentation. Nevertheless, no threshold has been proposed to evaluate the rumen digestive disorder. In order to initiate the use of ruminal $E_{h}$, we could propose a preliminary threshold of ruminal $E_{h}>-166 \mathrm{mV}$ (correspond to $\mathrm{pH}<6$ according to Equation (2)) indicating digestive disorder.

\section{Conclusion}

By gathering together a large database of uniformly measured ruminal $E_{h}$ and $p H$ under anaerobic conditions, the present study demonstrated a quadratic correlation between ruminal $E_{h}$ and $p H$. The analysis highlights the influence of dietary characteristics on ruminal $E_{h}$. Within experiments, a good prediction of ruminal $E_{h}$ could be made using soluble sugars content and the dietary ionic balance. The dietary characteristics ( $N D F, N D F f, O M$, starch, degradable starch, soluble sugars contents, and the dietary ionic balance) influencing the ruminal $p H$ also affected the ruminal $E_{h}$, but not always in same extent. Some of them still influence the relationship between ruminal $E_{h}$ and $p H$. The mechanism of the interaction between ruminal $E_{h}$ and $p H$ remains to be elucidated; it would be interesting to associate microbial profile and ruminal VFA concentration and milk production performance in future studies.

\section{Acknowledgements}

We would like to thank Prof. Philippe Schmidely for his help in the statistical analysis of the results.

\section{References}

[1] Husson, O. (2013) Redox potential (Eh) and pH as Drivers of Soil/Plant/ Microorganism Systems, A Transdisciplinary Overview Pointing to Integrative Opportunities for Agronomy. Plant Soil, 362, 389-417. https://doi.org/10.1007/s11104-012-1429-7

[2] Falkowski, P.G., Fenchel, T. and Delong, E.F. (2008) The Microbial Engines That Drive Earth's Biogeochemical Cycles. Science, 320, 1034-1039. https://doi.org/10.1126/science.1153213

[3] Brasca, M., Morandi, S., Lodi, R. and Tamburini, A. (2007) Redox Potential to Discriminate among Species of Lactic Acid Bacteria. Journal of Applied Microbiology, 103, 1516-1524. https://doi.org/10.1111/j.1365-2672.2007.03392.x

[4] Tomlinson, J.W. and Kilmartin, P.A. (1997) Measurement of the Redox Potential of Wine. Journal of Applied Electrochemistry, 27, 1125-1134. https://doi.org/10.1023/A:1018407230924

[5] Marounek, M., Bartos, S. and Kalachnyuk, G.I. (1982) Dynamics of the Redox Potential and $\mathrm{rH}$ of the Rumen Fluid of Goats. Physiologia Bohemoslovenica, 31, 369-374.

[6] Marden, J.P., Bayourthe, C., Enjalbert, F. and Moncoulon, R. (2005) A New Device for Measuring Kinetics of Ruminal $\mathrm{pH}$ and Redox Potential in Dairy Cows. Journal of Dairy Science, 88, 277-281. https://doi.org/10.3168/jds.S0022-0302(05)72685-0 
[7] Julien, C., Marden, J.P., Bonnefont, C., Moncoulon, R., Auclair, E., Monteils, V. and Bayourthe, C. (2010) Effects of Varying Proportions of Concentrates on RuminalReducing Power and Bacterial Community Structure in Dry Dairy Cows Fed Hay-Based Diets. Animal, 4, 1641-1646. https://doi.org/10.1017/S1751731110000972

[8] Broberg, G. (1958) Measurements of the Redox Potential in Rumen Contents. IV. In vivo measurements. Nordisk Veterinaermedicin, 10, 263-268.

[9] De Laune, R.D. and Reddy, K.R. (2005) Redox Potential. In: Hillel, D., Ed., Encyclopedia of Soils in the Environment, Elsevier Ltd., Amsterdam, 366-371. https://doi.org/10.1016/B0-12-348530-4/00212-5

[10] Pinloche, E., McEwan, N., Marden, J.P., Bayourthe, C., Auclair, E. and Newbold, C. J. (2013) The Effects of a Probiotic Yeast on the Bacterial Diversity and Population Structure in the Rumen of Cattle. PloS ONE, 8, e67824. https://doi.org/10.1371/journal.pone.0067824

[11] Sauvant, D. and Peyraud, J.L. (2010) Diet Formulation and Risk Assessment of Acidosis. INRA Productions Animales, 23, 333-342.

[12] Plaizier, J.C., Khafipour, E., Li, S., Gozho, G.N. and Krause, D.O. (2012) Subacute Ruminal Acidosis (SARA), Endotoxins and Health Consequences. Animal Feed Science and Technology, 172, 9-21.

[13] Andrade, P.V.D., Giger-Reverdin, S. and Sauvant, D. (2002) Relationship between Two Parameters (pH and Redox Potential) Characterizing Rumen Status. Rencontres Recherches Ruminants, 9, 332.

[14] Giger-Reverdin, S., Rigalma, K., Desnoyers, M., Sauvant, D. and Duvaux-Ponter, C. (2014) Effect of Concentrate Level on Feeding Behavior and Rumen and Blood Parameters in Dairy Goats, Relationships between Behavioral and Physiological Parameters and Effect of Between-Animal Variability. Journal of Dairy Science, 97, 4367-4378. https://doi.org/10.3168/jds.2013-7383

[15] Penner, G.B., Beauchemin, K.A. and Mutsvangwa, T. (2006) An Evaluation of the Accuracy and Precision of a Stand-Alone Submersible Continuous Ruminal pH Measurement System. Journal of Dairy Science, 89, 2132-2140. https://doi.org/10.3168/jds.S0022-0302(06)72284-6

[16] Qin, C., Bu, D., Sun, P., Zhao, X., Zhang, P. and Wang, J. (2017) Effects of Corn Straw or Mixed Forage Diet on Rumen Fermentation Parameters of Lactating Cows Using a Wireless Data Logger. Animal Science, 88, 259-266. https://doi.org/10.1111/asj.12616

[17] Mathieu, F., Jouany, J.P., Senaud, J., Bohatier, J., Bertin, G. and Mercier, M. (1996) The Effect of Saccharomyces cerevisiae and Aspergillus oryzae on Fermentations in the Rumen of Faunated and Defaunated Sheep: Pprotozoal and Probiotics Interactions. Reproduction Nutrition Development, 36, 271-287. https://doi.org/10.1051/rnd:19960305

[18] Marden, J.P., Julien, C., Monteils, V., Auclair, E., Moncoulon, R. and Bayourthe, C. (2008) How Does Live Yeast Differ from Sodium Bicarbonate to Stabilize Ruminal $\mathrm{pH}$ in High Yielding Dairy Cows? Journal of Dairy Science, 91, 3528-3535. https://doi.org/10.3168/jds.2007-0889

[19] Barry, T.N., Thompson, A. and Armstrong, D.G. (1977) Rumen Fermentation Studies on Two Contrasting Diets. 1. Some Characteristics of the in Vivo Fermentation, with Special Reference to the Composition of the Gas Phase, Oxidation/Reduction State and Volatile Fatty Acid Proportions. The Journal of Agricultural Science, 89, 183-195. https://doi.org/10.1017/S0021859600027362

[20] Michelland, R.J., Monteils, V., Combes, S., Cauquil, L., Gidenne, T. and Fortun- 
Lamothe, L. (2011) Changes over Time in the Bacterial Communities Associated with Fluid and Food Particles and the Ruminal Parameters in the Bovine Rumen before and after a Dietary Change. Canadian Journal of Microbiology, 57, 629-637. https://doi.org/10.1139/w11-053

[21] Monteils, V., Rey, M., Cauquil, L., Troegeler-Meynadier, A., Silberberg, M. and Combes, S. (2011) Random Changes in the Heifer Rumen in Bacterial Community Structure, Physico-Chemical and Fermentation Parameters, and in Vitro Fiber Degradation. Livestock Science, 141, 104-112.

[22] Julien, C., Marden, J.P., Auclair, E., Moncoulon, R., Cauquil, L., Peyraud, J.L. and Bayourthe, C. (2015) Interaction between Live Yeast and Dietary Rumen Degradable Protein Level: Effects on Diet Utilization in Early-Lactating Dairy Cows. Agricultural Sciences, 6, 1-13. https://doi.org/10.4236/as.2015.61001

[23] Marden, J.P. (2007) The Mode of Action of the Yeast Saccharomyces cerevisiae Sc 47 in Ruminants: A Thermodynamic Approach in Dairy Cows. PhD Thesis, INP Toulouse, Toulouse, $195 \mathrm{p}$.

[24] Julien, C. (2011) Interactions between Diet Composition and Live Yeast Sc47 (ACTISAF R): Effects on Redox Status and Fermentative Activity in the Rumen of Dairy Cows. PhD Thesis, INP Toulouse, Toulouse, 235.

[25] Anonymous (1988) Order of 18 April 1988 Laying down the Conditions for Granting Authorization to Experiment. Journal Officiel de la République Française, 56085610 .

[26] Streeter, M.N., Wagner, D.G., Hibberd, C.A. and Owens, F.N. (1990) Comparison of Corn with Four Sorghum Grain Hybrids: Site and Extent of Digestion in Steers. Journal of Animal Science, 68, 3429-3440. https://doi.org/10.2527/1990.68103429x

[27] Chapoutot, P., Nozière, P. and Sauvant, D. (2013) "Systool”, a New Calculator for the New French "Systali" Project. 64th Annual Meeting of the European Federation of Animal Science, Nantes, 138.

[28] Sauvant, D. and Nozière, P. (2016) Quantification of the Main Digestive Processes in Ruminants: The Equations Involved in the Renewed Energy and Protein Feed Evaluation Systems. Animal, 10, 755-770. https://doi.org/10.1017/S1751731115002670

[29] Ross, J.G., Spears, J.W. and Garlich, J.D. (1994) Dietary Electrolyte Balance Effects on Performance and Metabolic Characteristics on Finishing Steers. Journal of Animal Science, 72, 1600-1607.

[30] Meschy, F. (2010) Mineral Nutrition of Ruminants. Editions Quae, Versailles.

[31] Apper-Bossard, E., Faverdin, P., Meschy, F. and Peyraud, J.L. (2010) Effects of Dietary Cation-Anion Difference on Ruminal Metabolism and Blood Acid-Base Regulation in Dairy Cows Receiving Two Contrasting Levels of Concentrate in Diets. Journal of Dairy Science, 93, 4196-4210. https://doi.org/10.3168/jds.2009-2975

[32] INRA (2007) Feeding of Cattle, Sheep and Goats. Tables INRA 2007, Editions Quae, Versailles.

[33] Nordstrom, D.K. (1977) Thermochemical Redox Equilibria of Zo Bell's Solution. Geochimicaet Cosmochimica Acta, 41, 1835-1841.

[34] Huang, Y., Julien, C., Marden, J.P. and Bayourthe, C. (2016) Relationship between Ruminal Redox Potential and $\mathrm{pH}$ in Dairy Cattle. Proceedings of the 20th Congress of the ESVCN, Berlin, 123.

[35] Sauvant, D., Schmidely, P., Daudin, J.J. and St-Pierre, N.R. (2008) Meta-Analyses of 
Experimental Data in Animal Nutrition. Animal, 2, 1203-1214. https://doi.org/10.1017/S1751731108002280

[36] St-Pierre, N.R. (2001) Invited Review: Integrating Quantitative Findings from Multiple Studies Using Mixed Model Methodology. Journal of Dairy Science, 84, 741755. https://doi.org/10.3168/jds.S0022-0302(01)74530-4

[37] Wang, Z. and Goonewardene, L.A. (2004) The Use of MIXED Models in the Analysis of Animal Experiments with Repeated Measures Data. Canadian Journal of Animal Science, 84, 1-11. https://doi.org/10.4141/A03-123

[38] Krizova, L., Richter, M., Trinacty, J., Ríha, J. and Kumprechtova, D. (2011) The Effect of Feeding Live Yeast Cultures on Ruminal pH and Redox Potential in Dry Cows as Continuously Measured by a New Wireless Device. Czech Journal of Animal Science, 56, 37-45.

[39] Pitt, R.E., Van Kessel, J.S., Fox, D.G., Pell, A.N., Barry, M.C. and Van Soest, P.J. (1996) Prediction of Ruminal Volatile Fatty Acids and pH within the Net Carbohydrate and Protein System. Journal of Animal Science, 74, 226-244. https://doi.org/10.2527/1996.741226x

[40] Kolver, E.S. and De Veth, M.J. (2002) Prediction of Ruminal pH from PastureBased Diets. Journal of Dairy Science, 85, 1255-1266.

https://doi.org/10.3168/jds.S0022-0302(02)74190-8

[41] Meschy, F. and Peyraud, J.L. (2004) Strong Ion Content of Forages, Dietary Cation Anion Difference and Acid-Base Balance Values. Rencontres Recherches Ruminants, 11, 255-258.

[42] Apper-Bossard, E., Peyraud, J.L. and Dourmad, J.Y. (2009) Effects of Dietary Cation-Anion Difference on Performance and Acid-Base Status: A Review. INRA Productions Animales, 22, 117-130.

[43] Apper-Bossard, E., Peyraud, J.L., Faverdin, P. and Meschy, F. (2006) Changing Dietary Cation-Anion Difference for Dairy Cows Fed with Two Contrasting Levels of Concentrate in Diets. Journal of Dairy Science, 89, 749-760. https://doi.org/10.3168/jds.S0022-0302(06)72136-1

[44] Hu, W. and Murphy, M.R. (2004) Dietary Cation-Anion Difference Effects on Performance and Acid-Base Status of Lactating Dairy Cows: A Meta-Analysis. Journal of Dairy Science, 87, 2222-2229. https://doi.org/10.3168/jds.S0022-0302(04)70042-9

[45] Iwaniuk, M.E., Weidman, A.E. and Erdman, R.A. (2015) The Effect of Dietary Cation-Anion Difference Concentration and Cation Source on Milk Production and Feed Efficiency in Lactating Dairy Cows. Journal of Dairy Science, 98, 1950-1960. https://doi.org/10.3168/jds.2014-8704

[46] Giger-Reverdin, S., Duvaux-Ponter, C., Rigalma, K. and Sauvant, D. (2006) Effect of Chewing Behaviour on Ruminal Redox Potential Variability in Dairy Goats. Rencontres Recherches Ruminants, 13, 138.

[47] Krishtalik, L.I. (2003) pH-Dependent Redox Potential: How to Use It Correctly in the Activation Energy Analysis. Biochimicaet Biophysica Acta, 1604, 13-21.

[48] Bohn, H.L. (1969) The EMF of Platinum Electrodes in Dilute Solutions and Its Relation to Soil pH. Soil Science Society of America Journal, 33, 639-640. https://doi.org/10.2136/sssaj1969.03615995003300040044x

[49] Friedman, N., Shriker, E., Gold, B., Durman, T., Zarecki, R. and Mizrahi, I. (2017) Diet-Induced Changes in Redox Potential Underlie Compositional Shifts in the Rumen Archaeal Community. Environmental Microbiology, 191, 174-184. https://doi.org/10.1111/1462-2920.13551 
Submit or recommend next manuscript to SCIRP and we will provide best service for you:

Accepting pre-submission inquiries through Email, Facebook, LinkedIn, Twitter, etc. A wide selection of journals (inclusive of 9 subjects, more than 200 journals)

Providing 24-hour high-quality service

User-friendly online submission system

Fair and swift peer-review system

Efficient typesetting and proofreading procedure

Display of the result of downloads and visits, as well as the number of cited articles Maximum dissemination of your research work

Submit your manuscript at: http://papersubmission.scirp.org/

Orcontact as@scirp.org 